\title{
KONSEP KETERASINGAN DALAM FILM "AISYAH BIARKAN KAMI BERSAUDARA" KARYA HERWIN NOVIANTO
}

\author{
Susiati \\ Universitas Iqra Buru \\ Jalan Prof. Dr. H. A.R. Basalamah No. 20, Namlea, Buru \\ Telepon (0913) 21909, Pos-el: susiatiuniqbu@gmail.com
}

\begin{abstract}
Abstrak
Penelitian ini bertujuan mendeskripsikan konsep keterasingn dalam film "Aisyah Biarkan Kami Bersaudara" karya Herwin Novianto. Penelitian ini merupakan penelitian kualitatif. Data dikumpulkan menggunakan metode audio visual, yakni dengan melihat dan mendengar suatu objek dari gambar dan suara. Sementara itu, teknik pengumpulan data menggunakan teknik simak dan catat. Data dianalisis secara deskriptif sesuai dengan teori konsep eksistensi manusia Koeswara yang meliputi empat jenis, yakni kebersamaan dan cinta, pertentangan, keterasingan dan kesepian, serta kematian. Hasil penelitian menunjukkan bahwa konsep keterasingan manusia dalam film "Aisyah Biarkan Kami Bersaudara" karya Herwin Novianto meliputi kesedihan, kegelisahan, kejengkelan, kekhawatiran, ketakutan, dan kebohongan.
\end{abstract}

Kata kunci: konsep keterasingan, film, Aisyah Biarkan Kami Bersaudara 


\section{Pendahuluan}

Sastra merupakan bagian dari manifestasi keadaan sosial kemasyarakatan. Karya sastra adalah suatu wujud yang mencerminkan perilaku, kejadian, keunikan, keberagaman masyarakat dalam setiap kurun waktu tertentu. Segala wujud cerminan masyarakat dapat digubah dalam sebuah sketsa karya sastra dengan tidak menghilangkan nilai rasa asli dari kenyataan yang terjadi dalam masyarakat.

Inovasi dalam sastra terus berkembang. Hal ini disebabkan sastra merupakan hasil penjumlahan atau ketegangan antara konvensi dan inovasi (Teeuw, 1980). Jika konvensi terlalu besar, sastra bersifat konvensional. Namun, kalau konvensi itu dikalahkan oleh inovasi, sastra dapat bersifat inkonvensional.

Dari dua masalah di atas, sastra semakin mengembangkan sayapnya dari yang bersifat tekstual hingga yang bersifat visual. Cerpen, novel, dan drama sekarang sudah dapat ditonton dalam bentuk film. Buku teori sastra masa kini, An Introduction to Literary Studies (1998) yang ditulis oleh seorang profesor bahasa Inggris pada Studi Amerika, Universitas Innsbruck, bernama Mario Klarer, secara khusus memasukkan genre film sebagai karya sastra. Dalam buku itu, Klarer juga membahas secara padat ihwal fiksi (fiction), puisi (poetry), drama, dan film. Pendapat Klarer mengenai film sebagai karya sastra dikutip berikut ini.

At the end of the twentieth century, it is impossible to neglect film as a semi-textual genre both influenced by and exerting influence on literature and literary critism. Film is predetermined by literary techniques, conversely, literary practice developed particular features under the impact of film. Many of the dramatic forms in the twentieth century, for example, have evolved in interaction with film, whose means of photographic depiction far surpass the means of realistic portrayal in the theater.

Film's idiosyncratic of presentation-such as camera angle, editing, montage, slow and fast motion-often parallel features of literary texts or can be explained within a textual framework (Klarer, 1998:57).

Menurut Mario Klarer, sebagaimana terdapat dalam kutipan di atas, film termasuk karya sastra dan segala macam mode presentasi film sesuai dengan fitur-fitur teks sastra dan dapat pula dijelaskan dalam kerangka tekstual. Dengan demikian, film adalah pergerakan kontemporer dari mode sastra tekstual ke mode sastra visual.

Karya sastra tidak terlepas dari eksistensi manusia. Tokoh-tokoh yang menjadi subjek atau pelaku dalam penceritaan akan mencerminkan karakter individu atau karakter sosial tertentu. Artinya, jika karya sastra tersebut berasal dari daerah bagian timur Indonesia, perwujudan eksistensi manusia tidak akan terlepas dari kebiasaan atau keadaan nyata masyarakat di sana.

Manusia, dengan eksistensi dan segala pengetahuan yang dimiliki, memungkinkan dapat beradaptasi dengan lingkungannya. Van der Weij (1988: 39) mengatakan bahwa manusia merupakan ciptaan Tuhan yang ada di muka bumi dan merupakan satu-satunya makhluk yang memiliki kemampuan berfikir dan merefleksikan segala sesuatu yang ada, termasuk diri dan keberadaannya di dunia. Kemampuan itulah yang membedakan manusia dengan makhluk lain, seperti binatang.

Karya sastra mempunyai dua aspek penting, yakni isi dan bentuk. Isi berupa pengalaman hidup manusia, sedangkan bentuk berupa cara penilaian, yaitu cara sastrawan memanfaatkan bahasa yang indah untuk mewadahi isinya (Semi, 1989: 8). Sementara itu, Pradopo (2003: 113) berpendapat bahwa karya sastra diciptakan oleh pengarang dengan tidak terlepas dari masyarakat dan budayanya. Sering kali sastrawan menonjolkan kekayaan budaya masyarakat, suku bangsa, atau bangsanya.

Hal yang sama terdapat dalam karya film. Sutradara film di Indonesia selalu menonjolkan eksistensi sosial budaya masyarakat dalam setiap karya mereka. Sebagai media hiburan dan wadah luapan ekspresi, film juga merupakan sarana pemaparan atas realitas sosial yang terjadi di kehidupan nyata. Secara visual film dapat menampilkan keadaan yang sangat mirip dengan yang sesungguhnya yang sedang terjadi di tengah-tengah masyarakat (Dila, 2017: 78). 
Pada dasarnya antara sastra dan masyarakat terdapat hubungan yang hakiki. Menurut Ratna (2004: 60), hubungan itu terjadi disebabkan oleh (a) karya sastra diciptakan oleh pengarang; (b) pengarang itu sendiri adalah anggota masyarakat; (c) pengarang memanfaatkan kekayaan yang ada dalam masyarakat; dan (d) hasil karya itu dapat dimanfaatkan kembali oleh masyarakat.

Sastra tidak lahir dalam situasi kekosongan eksistensi manusia. Eksistensi menampakkan suatu keadaan masyarakat yang telah memiliki tradisi, adat istiadat, konvensi, keyakinan, pandangan hidup, cara hidup, cara berpikir, pandangan tentang astetika, dan lain sebagainya. Sastra dapat dipandang sebagai bagian integral dari kehidupan sosial budaya masyarakat yang melahirkannya. Selain itu, sastra muncul karena masyarakat menginginkan legitimasi kehidupan sosial budayanya, tepatnya legitimasi eksistensi kehidupannya. Sebagai disiplin yang berbeda, sastra dan sosial budaya memiliki objek yang sama, yakni manusia dalam masyarakat, manusia sebagai fakta sosial, manusia sebagai makhluk kultural.

Sementara itu, dalam penelitian ini, film "Aisyah Biarkan Kami Bersaudara" karya Herwin Novianto menjadi objek karena memiliki gambaran eksistensi manusia yang menyuguhkan cerita tentang persaudaraan (toleransi antarumat beragama) dan pendidikan. Film "Aisyah Biarkan Kami Bersaudara" menjalankan fungsinya sebagai cermin sosial dengan tokoh Aisyah dan anak-anak Nusa Tenggara Timur yang menjadi refleksi agar negeri ini tidak mudah terbelah atau terprovokasi.

Film "Aisyah Biarkan Kami Bersaudara" memaparkan keadaan secara realistis bagaimana wajah pendidikan Indonesia di daerah terpencil Indonesia serta perjuangan seorang guru yang menunjukkan jiwa nasionalis, survivor, dan pengabdian yang totalitas dengan tidak memedulikan masalah ras dan agama meskipun masalah ras dan agama tersebut masih menjadi permasalahan di masyarakat.

Herwin Novianto adalah sutradara film yang andal. Kemampuannya di dunia perfilman telah memberikan kontribusi yang besar bagi kemajuan perfilman yang berkualitas di Indonesia. Film "Aisyah Biarkan Kami Bersaudara" merupakan salah satu film yang menggambarkan realita kehidupan sosial masyarakat daerah terpencil di pedalaman Nusa Tenggara Timur. Film yang diproduksi pada 2016 itu digarap oleh rumah produksi film One Productions dan diangkat dari kisah nyata seorang wanita muslim yang menjadi guru di sebuah desa terpencil: Dusun Derok, Kecamatan Biboki Anleu, Kabupaten Timur Tengah Utara, Provinsi Nusa Tenggara Timur, yang penduduknya mayoritas beragama Kristen.

Film "Aisyah Biarkan Kami Bersaudara" berkisah tentang seorang sarjana pendidikan dari desa kecil di daerah Atambua, Nusa Tenggara Timur, bernama Aisyah. Seperti kebanyakan sarjana pendidikan lainnya, Aisyah bercita-cita dan ingin mengabdikan hidupnya untuk menjadi seorang guru yang bersahaja dan mampu memperbaiki kualitas pendidikan di Indonesia.

Penilitian ini bertujuan untuk mendeskripsikan konsep keterasingan dalam film "Aisyah Biarkan Kami Bersaudara" karya Herwin Novianto.

Eksistensi biasanya dijadikan sebagai acuan pembuktian diri bahwa kegiatan atau pekerjaan yang dilakukan seseorang dapat berguna dan mendapat nilai yang baik di mata orang lain. Selain itu, eksistensi juga dianggap sebagai sebuah istilah yang bisa diapresiasi kepada seseorang yang sudah banyak memberi pengaruh positif kepada orang lain.

Adapun tahap-tahap eksistensi manusia adalah sebagai berikut.

(1) Tahap estetis, yakni tahap yang orientasi hidup manusia sepenuhnya diarahkan untuk mendapatkan kesenangan. Pada tahap ini manusia dikuasai oleh nalurinaluri seksual oleh prinsip-prinsip kesenangan yang hedonistik dan biasanya bertindak menurut suasana hati.

(2) Tahap etis, yakni mengubah pola hidup yang semula estetis menjadi etis. Ada semacam "pertobatan" yang setiap individu mulai menerima dan menghayati 
nilai-nilai kemanusiaan yang dipilihnya secara bebas.

(3) Tahap religius, yakni, keotentikan hidup manusia sebagai subjek baru akan tercapai seandainya individu dengan mata tertutup lompat dan meleburkan diri ke dalam realitas Tuhan. Lompatan dari tahap etis ke tahap religius jauh lebih sulit daripada lompatan dari tahap estetis ke tahap etis.

Menurut Abidin (2007: 18-28), eksistensi dalam kehidupan manusia, antara lain, berupa (1) proses dinamis yang terjadi pada diri manusia; (2) pemberian makna; (3) esensi; (4) keautentik dan ketidakautentik; (5) kematian; (6) kecemasan; (7) kehendak bebas; (8) waktu; (9) ruang; (10) tubuh; (11) diri sendiri; (12) pilihan; dan (13) rasa bersalah.

Titik sentral persoalan dalam gerakan eksistensialisme adalah berbagai hal yang berubungan dengan eksistensi manusia. Berkaitan dengan hal itu, para tokoh eksistensialisme telah mengembangkan dan menguraikan berbagai pandangan menyangkut keberadaan serta kondisi-kondisi atau ciri-ciri fundamental yang ada pada manusia.

Menurut Koeswara (2002: 9), pandanganpandangan tersebut telah diterima dan disepakati secara luas untuk menjadi titik tolak atau tumpuan pikiran. Tidak saja bagi pikiran filosofis para eksistensialis, tetapi juga manjadi titik tolak bagi pemikir dan kegiatan praktis para ahli psikologis eksistensial.

Konsep atau pandangan tentang eksistensi manusia yang dimaksud oleh Koeswara (2002: 15) meliputi kebersamaan dan cinta; pertentangan; kesepian dan keterasingan; dan kematian.

Konsep eksistensi manusia tentang kebersamaan adalah suatu konsep filsafat yang sangat umum dan telah dikenal sejak manusia mengenal filsafat yang muncul sejak manusia itu sendiri menjalani kehidupan bersama. Para eksistensialis percaya bahwa kebersamaan atau hidup dengan sesama bagi manusia bukan semata-mata merupakan kebetulan atau hanya suatu realistis, melainkan merupakan sesuatu yang seharusnya ada sebab kebersamaan adalah ciri yang esensial dari keberadaan manusia. Hubungan cinta yang sungguh-sungguh dijalani oleh dua pihak yang saling membuka diri, saling percaya, dan saling terlibat sambil memelihara partner cinta sebagai pribadi atau subjek (Koeswara, 2002: 15).

Pertentangan adalah suatu hubungan manusia yang bukan merupakan kerja sama. Jadi, usaha untuk membangun cinta sebagai hubungan pribadi yang sungguh-sungguh merupakan usaha yang sia-sia saja sebab bilamana aku mengadakan kontak dengan orang lain, dengan serentak aku ingin mengobjekkan orang lain itu (Koeswara, 2002: 17)

Kesepian merupakan tema yang dapat dijumpai dalam berbagai sistem filsafat, dengan pemahaman yang berbeda-beda. Sebagai filsafat personalitis yang memandang individualitas manusia sebagai realitas dasar, eksistensialisme memandang kesepian sebagai kemungkinan manusia yang selalu ada atau bisa dialami dan tidak akan pernah terhapus. Para eksistensialis percaya bahwa kesepian bersumber pada kekosongan jiwa dan kesepian itu sendiri dialami individu-individu dengan berbagai bentuk perasaan yang mengikutinya, seperti rasa jenuh, takut, dan gelisah (Koeswara, 2002: 18).

Apresiasi mempunyai arti pengamatan, penilaian, dan penghargaan ataupun pengenalan terhadap suatu karya seni. Mengapresiasi mengandung sejumlah pengertian yang tidak dapat dipisahkan satu sama lain. Dalam hubungan dengan film, apresiasi juga mengandung pengertian memahami, menikmati, dan menghargai (Sumarno, 1996).

Ada tiga tahapan dalam apresiasi film, yakni

a. Pemahaman

Berkaitan dengan keterlibatan emosional dan pikiran. Penonton memahami masalah, ide, ataupun gagasan, serta merasakan perasaanperasaan dan dapat membayangkan dunia rekaan yang ingin diciptakan.

1. Apa yang ingin dikatakan film itu?

2. Adakah gagasan yang tersirat?

3. Emosi macam apa yang ditawarkan?

4. Kebudayaan macam apa yang melahirkan film ini?

b. Penikmatan 
Keadaan penonton yang dalam memahami dan menghargai penguasaan pembuat film terhadap cara-cara penyajian pengalaman hingga dicapai tingkat penghayatan yang intens. Tidak seorang pun bisa menikmati karya film atau bahkan memahaminya, sampai seseorang mengerti bahasanya. Oleh karena itu, unsur-unsur film harus diselami.

1. Apakah film itu utuh?

2. Apakah semua unsur menyatu?

c. Penghargaan

Tahap ketika penonton memasalahkan dan menemukan hubungan pengalaman yang ia dapat dari karya film dengan pengalaman kehidupan nyata yang dihadapi. Pertemuan dengan jiwa atau roh film.

1. Seberapa jauh kita mendapatkan suatu pengalaman batin?

2. Seberapa jauh pandangan kita terhadap suatu aspek kehidupan lebih diperdalam?

\section{Metode Penelitian}

\subsection{Jenis Penelitian dan Pendekatan}

Penelitian ini adalah penelitian deskriptif kualitatif dengan menggunakan pendekatan filsafat sastra. Jenis penelitian deskriptif kualitatif merupakan salah satu prosedur penelitian yang menghasilkan data deskriptif berupa ucapan atau tulisan dan perilaku orangorang yang diamati (Bodgan dan Taylor dalam Moleong, 2007).

Sementara itu, pendekatan filsafat sastra digunakan untuk mengupas hakikat nilai-nilai kehidupan manusia yang terkandung dalam karya sastra.

\subsection{Metode dan Teknik Pengumpulan Data}

Metode yang digunakan dalam penelitian ini adalah metode audio visual, yakni dengan melihat dan mendengar suatu objek dari gambar dan suara. Sementara itu, teknik pengumpulan data menggunakan teknik simak. Teknik simak dilakukan oleh peneliti dengan menyimak dan melihat secara teliti keseluruhan film "Aisyah Biarkan Kami Bersaudara" karya Herwin Novianto yang berupa dialog dan gambargambar yang mencerminkan eksistensi manusia dalam film "Aisyah Biarkan Kami Bersaudara" karya Herwin Novianto.

\subsection{Sumber dan Jenis Data}

Sumber data dalam penelitian ini adalah film "Aisyah Biarkan Kami Bersaudara" karya Herwin Novianto. Jenis data dalam penelitian ini adalah dialog dan gambar yang berupa kalimat dan adegan yang menggambarkan eksistensi manusia dalam film "Aisyah Biarkan Kami Bersaudara" karya Herwin Novianto.

\subsection{Teknik Analisis Data}

Analisis data dalam penelitian ini dilakukan dengan tahapan sebagai berikut.

1. Pengidentifikasian data, yakni mengidentifikasi eksistensi manusia melalui kalimat dan adegan antartokoh dalam film "Aisyah Biarkan Kami Bersaudara" karya Herwin Novianto.

2. Pengklasifikasian data, yakni mengklasifikasi kalimat dan adegan yang mencerminkan eksistensi manusia dalam film "Aisyah Biarkan Kami Bersaudara" karya Herwin Novianto.

3. Penganalisisan data, yakni semua data yang telah diklasifikasi dianalisis dengan mendeskripsikan secara mendetail permasalahan yang ada dalam penelitian ini berupa eksistensi manusia dalam film film "Aisyah Biarkan Kami Bersaudara" karya Herwin Novianto.

\section{Pembahasan}

Pembahasan dalam penelitian ini berupa pendeskripsian konsep keterasingan dalam film "Aisyah Biarkan Kami Bersaudara" yang menjadi fokus masalah.

Film "Aisyah Biarkan Kami Bersaudara" karya Herwin Novianto sarat dengan gambaran konsep eksistensi manusia dalam lingkungan masyarakat khususnya konsep keterasingan. Pengarang film memandang bahwa pendeskripsian kehidupan masyarakat yang mayoritas Kristiani menerima kedatangan minoritas (Islam) dalam keseharian mereka patut didokumentasikan.

Gambaran kehidupan sosial, budaya, dan kemasyarakatan masyarakat di bagian daerah terpencil Nusa Tenggara Timur terangkum dengan apik dalam film "Aisyah Biarkan Kami Bersaudara". Dalam mendeskripsikan konsep 
keterasingan, penulis menggunakan teori konsep eksistensi manusia Koeswara yang meliputi empat jenis, yakni kebersamaan dan cinta, pertentangan, keterasingan dan kesepian, serta kematian.

\section{Konsep Keterasingan dalam Film "Aisyah Biarkan Kami Bersaudara" Karya Herwin Novianto}

Konsep kesepian dan keterasingan adalah sebuah gambaran keadaan manusia dalam hal atau keadaan terasing dan sepi dari manusia lain. Dalam film "Aisyah Biarkan Kami Bersaudara" karya Herwin Novianto terdapat beberapa konsep kesepian dan keterasingan yang menampilkan nuansa sedih. Berikut pembahasannya.

Tabel 3

Konsep Kesepian dan Keterasingan

\begin{tabular}{|l|l|}
\hline No. & $\begin{array}{c}\text { Konsep Kesepian dan Keterasingan } \\
\text { dalam film "Aisyah Biarkan Kami } \\
\text { Bersaudara" }\end{array}$ \\
\hline 1. & Kesedihan \\
\hline 2. & Kegelisahan \\
\hline 3. & Kejengkelan \\
\hline 4. & Kekhawatiran \\
\hline 5. & Ketakutan \\
\hline 6. & Kebohongan \\
\hline
\end{tabular}

\section{Kesedihan}

Kesedihan adalah suatu emosi yang ditandai oleh perasaan tidak beruntung, kehilangan, dan ketidakberdayaan. Kesedihan merupakan bagian eksistensi manusia sebagai makhluk sosial.

Pendeskripsian eksistensi manusia dengan rasa sedih dalam film "Aisyah Biarkan Kami Bersaudara" tampak pada saat Lordis mengalami kecelakaan. Ia ditolong oleh Aisyah dan para siswa, dibawa ke rumah sakit. Namun, masih dalam masa perawatan, paman Lordis datang, lalu membuka infus Lordis dan memaksanya untuk keluar dari rumah sakit. Kesedihan dan ketidakberdayaan Lordis terlihat jelas karena Lordis tidak bisa melawan pamannya yang telah merawatnya selama ini.

\section{Kegelisahan}

Kegelisahan adalah keadaan psikologi dan fisiologis yang tidak tenteram dalam hati seseorang terhadap hal yang dialaminya. Kegelisahan merupakan bagian eksistensi manusia sebagai makhluk individu dan makhluk sosial.

Pendeskripsian eksistensi manusia dengan rasa gelisah dalam film "Aisyah Biarkan Kami Bersaudara" tampak pada saat Aisyah merasa gelisah terhadap keadaan keuangannya yang tidak mencukupi untuk pulang kampung saat lebaran Idulfitri.

\section{Kejengkelan}

Kejengkelan adalah perasaan kesal, dongkol terhadap sesuatu yang dialami manusia. Kejengkelan merupakan bagian eksistensi manusia sebagai makhluk sosial.

Berikut ini contoh data dialog dalam film "Aisyah Biarkan Kami Bersaudara" yang memperlihatkan kejengkelan.

(1) Kejengkelan Aisyah kepada Jaya yang akan pergi ke Aceh.

Ibu : Kenapa Nak?

Aisyah : Ya gitu Mah, Ajai dipindah tugaskan ke pulau Jawa

Ibu : Trus masalahnya teh naon?

Aisyah : Mendadak itu mama', nyebelin.

Contoh (11) di atas menggambarkan eksistensi Aisyah pada saat mengalami pergolakan batin, yakni merasa jengkel dengan sosok Ajai yang mendadak dipindahtugaskan ke luar Pulau Jawa. Pergolakan rasa jengkel yang ada pada diri Aisyah muncul karena hubungan mereka berdua belum ada kejelasan status.

\section{Kekhawatiran}

Kekhawatiran adalah sikap berpikir berlebihan atau terlalu cemas tentang suatu masalah atau situasi. Kekhawatiran merupakan bagian eksistensi manusia sebagai makhluk sosial.

Berikut ini gambar dan tuturan contoh data dalam film "Aisyah Biarkan Kami Bersaudara" yang memperlihatkan kekhawatiran.

(2) Kekhawatiran para siswa kepada Aisyah saat akan menjaga Lordis di rumah sakit.

Aisyah : Langsung pulang sama Pak Pedro ya?

Siku : Ei... sunde bisa Ibu, katong sunde bisa kas tinggal Ibu sendiri di sini deng Lordis.

Aisyah : Kenapa? Su usah khawatir Siku, ya? Beta sunde apa-apa. 
Contoh (12) di atas menggambarkan kekhawatiran para siswa terhadap Aisyah. Mereka mengkhawatirkan Aisyah berdekatan dengan Lordis karena mereka tahu bahwa Lordis sangat membenci Aisyah.

\section{Ketakutan}

Ketakutan adalah suatu tanggapan emosi terhadap ancaman bahaya atau rasa sakit. Ketakutan merupakan bagian eksistensi manusia sebagai makhluk individu dan makhluk sosial.

Berikut ini contoh data dialog dalam film "Aisyah Biarkan Kami Bersaudara" yang memperlihatkan rasa ketakutan.

(3) Siku rela berbohong kepada Aisyah dan neneknya.

Aisyah : Jadi siapa yang pukul kamu?

Siku : E ... suangge, Ibu

Aisyah : Suangge itu apa, Siku?

Siku : Manusia kuntilanak Ibu, dia bisa terbang macam burung.

Contoh (13) di atas menggambarkan ketakutan Siku untuk mengaku kepada Aisyah, Ibu Dusun, dan neneknya atas pemukulan Lordis kepadanya. Siku berbohong kepada tokoh lainnya bahwa yang memukulnya adalah setan yang biasa mereka sebut suangge. Hal ini dilakukan Siku karena dia sangat takut kepada Lordis.

\section{Kebohongan}

Kebohongan adalah bentuk pernyataan yang tidak benar, dengan niat untuk menjaga rahasia atau reputasi, perasaan, dan melindungi seseorang untuk menghindari hukuman atau menolak suatu perbuatan.

Pendeskripsian eksistensi manusia dengan kebohongan dalam film "Aisyah Biarkan Kami Bersaudara" tampak pada saat Siku membohongi para tokoh lain atas pemukulan yang dialaminya. Hal ini terlihat pada contoh data (13). Tokoh Siku menyembunyikan pelaku (Lordis) karena merasa takut nanti para tokoh lain mendatangi dan menghukum Lordis.

\section{Penutup}

Berdasarkan penelitian yang telah dilakukan, dapat disimpulkan beberapa hal yang terkait dengan konsep eksistensi manusia dalam film "Aisyah Biarkan Kami Bersaudara" karya Herwin Novianto.

Terdapat tiga konsep eksistensi manusia dalam film "Aisyah Biarkan Kami Bersaudara" karya Herwin Novianto, yakni (1) konsep kebersamaan dan cinta; (2) konsep pertentangan; serta (3) konsep keterasingan dan kesepian.

Konsep kebersamaan dan cinta merupakan gambaran keadaan manusia dalam sebuah hubungan yang positif yang ditampakkan melalui sikap suatu individu kepada individu yang lain. Bentuk konsep kebersamaan dan cinta dalam film "Aisyah Biarkan Kami Bersaudara" karya Herwin Novianto meliputi keakraban, saling membantu/kerja sama, menasehati, rasa saling menghormati dan menghargai, perhatian, tanggung jawab, keterbukaan, rasa iba, tepa salira, berkeyakinan, dan berkelakar. Konsep pertentangan merupakan pergolakan jiwa yang dirasakan oleh seseorang baik pengaruh lingkungan, batin, maupun kelompok manusia. Bentuk konsep pertentangan dalam film "Aisyah Biarkan Kami Bersaudara" karya Herwin Novianto meliputi ketidaksetujuan, ketidaksepahaman, rasa tidak menghargai, ketidakterimaan, ketidakpercayaan, dan kebencian.

Sementara itu, konsep keterasingan dan kesepian merupakan gambaran keadaan manusia dalam keadaan terasing dan sepi dari manusia lain. Bentuk konsep pertentangan dalam film "Aisyah Biarkan Kami Bersaudara" karya Herwin Novianto meliputi kesedihan, kegelisahan, kejengkelan, kekhawatiran, ketakutan, dan kebohongan.

\section{Daftar Pustaka}

Abidin, Zainal. 2007. Analisis Eksistensial, Sebuah Pendekatan Alternatif untuk Psikologi dan Psikiatri. Jakarta: PT Raja Grafindo.

Susiati, S. (2020). Eksistensi Manusia Dalam Film" Aisyah Biarkan Kami Bersaudara" Karya Herwin Novianto.

Bagus, Lorens. 2005. Kamus Filsafat. Jakarta: Gramedia Pustaka Utama. 
Susiati, S. Bahan Ajar: Psikolinguistik.

Dila, Putri Andini Kusumawardani. 2017. "Gambaran Eksistensi Tokoh Sandra dalam Film Deux Jours Une Nuit Karya Jean-Plerre Dardenne dan Luc Dardenne: Kajian Psikologi Eksistensial". Thesis. Universitas Brawijaya.

Susiati, S. (2020). Kaidah Fonologi Bahasa Indonesia.

Djojosuroto, Kinayati. 2007. Filsafat Bahasa. Yogyakarta: Pustaka Book.

Susiati, S. (2020). Morfologi Kelas Kata Dalam Bahasa Indonesia.

Klarer, Mario. 1998. An Introduction to Literary Studies. London: Routledge.

Susiati, S., \& Iye, R. (2018). Kajian Geografi Bahasa dan Dialek di Sulawesi Tenggara: Analisis Dialektometri. Gramatika: Jurnal Ilmiah Kebahasaan dan Kesastraan, 6(2), 137-151.

Koeswara. 2002. Psokologi Eksistensial Suatu Pengantar. Bandung: Rosda Offset.

Iye, R., Susiati, S., \& Karim, K. (2020). Citra Perempuan dalam Iklan Sabun Shinzui. Sang Pencerah: Jurnal Ilmiah Universitas Muhammadiyah Buton, 6(1), 1-7.

Moleong, Lexi. 2007. Metodologi Penelitian Kualitatif. Bandung: Remaja Rosdakarya.

Susiati, S., Iye, R., \& Suherman, L. O. A. (2019). Hot Potatoes Multimedia Applications in Evaluation of Indonesian Learning In SMP Students in Buru District. ELS Journal on Interdisciplinary Studies in Humanities, 2(4), 556-570.

Pradopo, Rahmat Djoko. 2003. Prinsip-prinsip Kritik Sastra. Yogyakarta: Gadjah Mada University Press.

Susiati, S. (2020). Pengaplikasian Multimedia Hot Potatoes Dalam Evaluasi Pembelajaran
Bahasa Indonesia Pada Siswa SMP Negeri 9 Buru.

Ratna, Nyoman Kutha. 2004. Paradigma Sosiologi Sastra. Yogyakarta: Pustaka Pelajar.

Susiati, S. (2020). Semantik: Teori Semantik, Relasi Makna, Marked, Dan Unmarked.

Semi, M. Atar. 1989. Kritik Sastra. Bandung: Angkasa.

Susiati, S. (2020). Kesantunan Imperatif Bahasa Melayu Ambon.

Sumarno, Marseli. 1996. Dasar-dasar Apresiasi Film. Jakarta: PT Grasindo.

Tafsir, Ahmad. 2006. Filsafat Pendidikan Islami. Jakarta: PT Remaja Rosdakarya.

Susiati, S. (2020). Fenomena Tuturan Emosi Verbal Bahasa Indonesia Suku Bajo Sampela.

Teeuw, A. 1984. Sastra dan Ilmu Sastra: Pengantar Teori Sastra. Jakarta: Pustaka Jaya.

Van der Weij, P. A. 1988. Filsuf-Filsuf Besar tentang Manusia (Terj.: K. Bertens). Gramedia: Jakarta.

Amanto, B. S., Umanailo, M. C. B., Wulandari, R. S., Taufik, T., \& Susiati, S. (2019). Local Consumption Diversification. Int. J. Sci. Technol. Res, 8(8), 1865-1869.

Susiati, S. (2020, June 18). Eksistensi Manusia Dalam Film "Aisyah Biarkan Kami Bersaudara" Karya Herwin Novianto. https://doi.org/10.31813/gramatika/7.1.2019.1 73.50--63

Iye, R., \& Susiati, S. (2018). NILAI EDUKATIF DALAM NOVEL SEBAIT CINTA DI BAWAH LANGIT KAIRO KARYA MAHMUD JAUHARI ALI (Educative Values in Sebait Cinta di Bawah Langit Kairo by Mahmud Jauhari Ali). Sirok Bastra, 6(2), 185-191. 
Susiati, S. (2018). Homonim bahasa kepulauan tukang besi dialek kaledupa di kabupaten wakatobi [the homonymon of tukang besi island languange in kaledupa dialect at wakatobi regency]. Totobuang, 6 (1), 109, 123.

Nurhayati, N., \& Said, I. (2019). Emosi Verbal Suku Bajo Sampela. Sosial Budaya, 16(2), 114126.

Susiati, S., \& Iye, R. (2018). Kajian Geografi Bahasa dan Dialek di Sulawesi Tenggara: Analisis Dialektometri. Gramatika: Jurnal Ilmiah Kebahasaan dan Kesastraan, 6(2), 137151.

Susiati, S. (2020). Kaidah Fonologi Bahasa Indonesia.

Harziko, H., Said, I. M., \& Darwis, K. (2018). FOLLOW THE EVENTS IN THE INDONESIAN LANGUAGE EXPRESSIVE SAID TRANSACTION IN THE TRADITIONAL MARKET TOWN OF BAUBAU. JURNAL ILMU BUDAYA, 6(1).

Susiati, S. (2020). Fenomena Tuturan Emosi Verbal Bahasa Indonesia Suku Bajo Sampela.

Andini, K. NILAI BUDAYA SUKU BAJO SAMPELA DALAM FILM THE MIRROR NEVER LIES KARYA KAMILA ANDINI.

Susiati, S. (2020). Nilai Budaya Suku Bajo Sampela Dalam Film The Mirror Never Lies Karya Kamila Andini.

Said, I. EMOSI VERBAL SUKU BAJO SAMPELA.

Susiati, S. (2020). Metode Pembelajaran Bahasa Indonesia: Sosiodrama.

Tahir, S. Z. B., Atmowardoyo, H., \& Dollah, S. (2018). BELAJAR BERBICARA MULTIBAHASA UNTUK SANTRI PESANTREN. Yogyakarta, Deepublish.

Susiati, S. (2020). Morfologi Kelas Kata Dalam Bahasa Indonesia.
Susiati, S. (2020). Fenomena Tuturan Emosi Verbal Bahasa Indonesia Suku Bajo Sampela.

Tenriawali, A. Y. (2018). Representasi korban kekerasan dalam teks berita daring tribun timur: analisis wacana kritis [the representation victims of violence in tribun timur online news text: critical discourse analysis]. TOTOBUANG, 6 (1), 1, 15.

Susiati, S., \& Iye, R. (2018). Kajian Geografi Bahasa dan Dialek di Sulawesi Tenggara: Analisis Dialektometri. Gramatika: Jurnal Ilmiah Kebahasaan dan Kesastraan. 6 (2), 137151.

Djamudi, N. L., Nurlaela, M., Nazar, A., Nuryadin, C., Musywirah, I., \& Sari, H. (2019, October). Alternative social environment policy through educational values in Kafi'a's customary speech to the kaledupa community of Wakatobi Island, Indonesia. In IOP Conference Series: Earth and Environmental Science (Vol. 343, No. 1, p. 012118). IOP Publishing.

Susiati, S. (2020). Gaya Bahasa Secara Umum Dan Gaya Bahasa Pembungkus Pikiran: Stilistika.

Susiati, Y. T. Risman Iye. A. Kesantunan Imperatif Bahasa Indonesia Suku Bajo Sampela: Balai Pembinaan dan Pengembangan Bahasa. 2018. Kongres Bahasa Indonesia (No. 12, pp. 1-6). Report.

Susiati, S. (2020). Kesantunan Imperatif Bahasa Melayu Ambon.

Mufidah, N., \& Tahir, S. Z. B. (2018). Empowering E-Learning As An Interactive Teaching For Arabic Learners. Lisanudhad, 5(2), 57-72.

Susiati, S. (2020). Gaya Bahasa Secara Umum Dan Gaya Bahasa Pembungkus Pikiran: Stilistika.

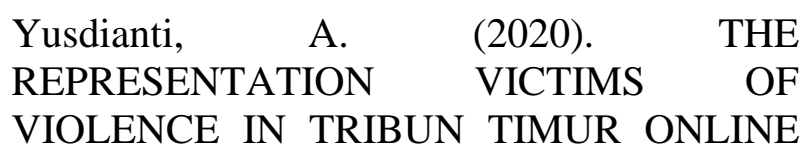


NEWS TEXT: CRITICAL DISCOURSE ANALYSIS.

Susiati, S. (2020). Tuturan Kesantunan Imperatif Bahasa Indonesia Suku Bajo Sampela.

Nacikit, J. PENTINGNYA MELESTARIKAN BAHASA DAERAH.

Susiati, S. (2020). Wujud Morfologi Bahasa Indonesia.

Susiati, S. (2020). Nilai Budaya Suku Bajo Sampela Dalam Film The Mirror Never Lies Karya Kamila Andini.

Taufik, T. (2019). Strategi AMBT untuk Meningkatkan Kemampuan Membaca Pemahaman Interpretatif Siswa Kelas IV SD Negeri 3 Namlea Kabupaten Buru. Sang Pencerah: Jurnal Ilmiah Universitas Muhammadiyah Buton, 5(2), 53-62.

Susiati, S. (2020). Morfologi Kelas Kata Dalam Bahasa Indonesia.

Rahayu, T. (2019). DIKSI DAN GAYA BAHASA PADA CERPEN ANAK DALAM MAJALAH MOMBI. Jurnal Pendidikan dan Pembelajaran Bahasa Indonesia, 8(2), 79-87.

Susiati, S. (2020). Kaidah Fonologi Bahasa Indonesia.

Afrianti, I. H., Chanafiah, Y., \& Agustina, E. ANALISIS TOKOH DALAM NOVEL JEJAK KUPU-KUPU KARYA AGNES JESICA DENGAN TINJAUAN PSIKOLOGI SASTRA (Doctoral dissertation, Universitas Bengkulu).

Susiati, S. (2020). PENTINGNYA MELESTARIKAN BAHASA DAERAH.

Wardani, Y., Priyadi, T., \& Sanulita, H. Struktur dan Makna Mantra Bekumpang Sastra Lisan Dayak Kantuk (Doctoral dissertation, Tanjungpura University).

Susiati, S. (2020). Makian Bahasa Wakatobi Dialek Kaledupa.
Siregar, J. A. K., Malik, A., \& Lestari, D. (2020). KEARIFAN LOKAL CERITA RAKYAT MASYARAKAT KABUPATEN KARIMUN KEPULAUAN RIAU. Jermal, 1(1), 1-14.

Susiati, S. (2020). Rekontruksi Internal Bahasa Bugis dan Bahasa Makassar: Linguistik Komparatif.

Basuki, N. V. A., \& Mulyono, M. (2018). Pengaruh Pelecehan Seksual Terhadap Pembentukan Perilaku Transgender pada Tokoh Sasana dalam Novel Pasung Jiwa Karya Okky Madasari: Kajian Psikologi Sastra. Jurnal Sastra Indonesia, 7(2), 95-100.

Susiati, S. (2020). Embrio Nasionalisme Dalam Bahasa dan Sastra.

Septarianto, T. W. (2018, November). MANISFESTASI NILAI-NILAI KEARIFAN LOKAL DALAM BUKU CERITA ANAK KECIL-KECIL PUNYA KARYA (KKPK)"LILI \&LYLIU”. In Seminar Internasional Riksa Bahasa (pp. 829-836).

Leja, W. NILAI PEMBENTUK KARAKTER MASYARAKAT WAKATOBI MELALUI KABHANTI WA LEJA.

Susiati, S. (2020). Teori dan Aliran Linguistik: Tata Bahasa Generatif.

Wahyuni, S. (2018). HUMOR DAN PESAN MORAL TEKS ANEKDOT PADA BUKU AJAR BAHASA INDONESIA KELAS $X$ SMA KURIKULUM 2013 (HUMOR AND MORAL MESSAGE OF ANECDOTAL TEXTS IN INDONESIAN LANGUAGE TEACHING MATERIALS FOR THE TENTH GRADE OF 2013 CURRICULUM SENIOR HIGH SCHOOL). JURNAL BAHASA, SASTRA DAN PEMBELAJARANNYA (JBSP), 7(2), 245-258.

Susiati, S. (2020). Semantik: Teori Semantik, Relasi Makna, Marked, Dan Unmarked.

Singgih, M., \& Surastina, S. (2019, June). NILAI-NILAI RELIGIUS DALAM NOVEL BIDADARI BERMATA BENING KARYA 
HABIBURRAHMAN EL-SHIRAZY DAN IMPLIKASINYA DI SEKOLAH. In Prosiding Seminar Nasional STKIP PGRI Bandar Lampung (pp. 215-222).

Susiati, S. (2020). Metode Pembelajaran Bahasa Indonesia: Sosiodrama.

Nugroho, R., \& Sunanda, A. (2019). Pendidikan Karakter dalam Novel Ratu Nyontek Karya Teresa Bertha: Tinjauan Sosiologi Sastra dan Relevansinya dalam Pembelajaran di SMA (Doctoral dissertation, Universitas Muhammadiyah Surakarta).

Susiati, S. PERWUJUDAN SIMILE OLEH MERARI SIREGAR DALAM NOVEL AZAB DAN SENGSARA.

Susiati, S. (2020, June 21). Bahan Ajar: Psikolinguistik.

https://doi.org/10.31219/osf.io/9hveb

Susiati, S. (2020). The Concept Of Togetherness In The Films" Aisyah Biarkan Kami Bersaudara" By Herwin Novianto.

Susiati, S. (2020). Konsep Pertentangan Dalam Film" Aisyah Biarkan Kami Bersaudara" Karya Herwin Novianto.

Susiati, S. (2020). Konsep Kebersamaan Dalam Film" Aisyah Biarkan Kami Bersaudara" Karya Herwin Novianto. 